\title{
Sistem Deteksi Masker dengan Metode Haar Cascade pada Era New Normal COVID-19
}

\author{
Ahmad Thariq ${ }^{\text {al }}$, Rizki Yusliana Bakti ${ }^{\text {b2 }}$ \\ a Jurusan Teknik Elektro, Politeknik Negeri Ambon \\ Jl. Ir. M. Putuhena, Rumah Tiga, Tlk. Ambon, Kota Ambon, Maluku \\ Iahmadthariq07@gmail.com \\ ${ }^{b}$ Universitas Muhammadiyah Makassar \\ Jl. Sultan Alauddin No.259, Gn. Sari, Kec. Rappocini, Kota Makassar, Sulawesi Selatan \\ 2rizkiyusliana@unismuh.ac.id
}

\begin{abstract}
Abstrak
Pandemi COVID-19 telah menyebabkan ribuan manusia terinfeksi virus COVID-19 dan meninggal dunia. Pada saat ini telah di berlakukan peraturan di mana setiap orang wajib menggunakan masker dan melakukan physical distancing pada saat keluar rumah. Penggunaan masker dan physical distancing telah beroperasi pada lingkungan perusahaan yang mewajibkan karyawannya menggunakan masker sebelum masuk ke kantor. Agar kebiasaan disiplin menggunakan masker di kantor dapat berjalan dengan baik, maka dibuatlah sistem deteksi masker dengan metode haar cascade pada era new normal COVID-19. Sistem deteksi masker ini menggunakan tools pycharm community edition 2020 dan python 3.8 module docs. Metode haar cascade digunakan untuk mendeteksi objek bermasker dan tidak bermasker. Hasil dari penelitian ini adalah sistem dapat mendeteksi orang yang menggunakan masker dan alarm akan berbunyi jika ada salah satu karyawan yang tidak
\end{abstract} menggunakan masker pada saat di dalam kantor.

Kata kunci: Pandemi COVID-19, Haar Cascade, masker

\section{Mask Detection System using Haar Cascade Method in New Normal Era of COVID-19}

\begin{abstract}
The COVID-19 pandemic has caused thousands of people to be infected with the COVID-19 virus and die. Currently, a regulation has been enforced where everyone is required to wear a mask and carry out physical distancing when leaving the house. The use of masks and physical distancing has been applied to companies that require employees to wear masks before entering the office. For the discipline to use masks in the office to run well, a mask detection system with the haar cascade method was created in the new normal era of COVID-19. This mask detection system uses the pycharm community edition 2020 tools and the python 3.8 module docs. The haar cascade method is used to detect masked and non-masked objects. The result of this research is that the system can detect people using masks and an alarm will sound if there is one employee who is not wearing a mask while in the office.
\end{abstract}

Keywords: COVID-19 pandemic, Haar Cascade, mask

\section{Pendahuluan}

Sejak Desember 2019, dunia digemparkan dengan munculnya COVID-19 yang merupakan penyakit pernafasan akut. Penyakit ini disebabkan oleh virus corona yang bernama severe acute respiratory syndrome coronavirus 2 atau disingkat SARS CoV-2 [1]. Hingga 17 Juni 2020, World Health Organization (WHO) mencatat bahwa terdapat 8.061.550 orang terinfeksi COVID-19 dan 440.290 orang meninggal dunia [2].

COVID-19 melanda Indonesia sejak Maret 2020. Jumlah kasus baru di indonesia setiap harinya masih terjadi peningkatan. Pemerintah selaku pembuat kebijakan, memberlakukan peraturan bagi setiap orang yang akan keluar rumah wajib menggunakan masker dan juga tetap melakukan physical distancing agar setiap orang dapat keluar rumah dan melakukan pekerjaan tanpa harus khawatir terpapar virus COVID-19 ini. Dengan adanya himbauan ini, diharapkan setiap masyarakat mampu untuk mematuhi penggunaaa masker. Ada beberapa faktor yang mempengaruhi kepatuhan masyarakat termasuk pengetahuan, motivasi, persepsi, dan keyakinan terhadap upaya pengontrolan dan pencegahan penyakit, variabel lingkungan, kualitas intruksi kesehatan, dan kemampuan mengakses sumber yang ada [3]. Ketidakpatuhan adalah 
kondisi ketika individu atau kelompok berkeinginan untuk patuh, tetapi ada sejumlah faktor yang menghambat kepatuhan terhadap saran tentang kesehatan yang diberikan oleh tenaga kesehatan [4]. Selain itu ketidakpatuhan juga berarti sejauh mana perilaku seseorang dan atau pemberi asuhan sejalan atau tidak sejalan dengan rencana promosi kesehatan atau rencana terapeutik yang disetujui antara orang tersebut (atau pemberi asuhan) dan professional layanan Kesehatan [5]. Penularan virus COVID-19 ini sendiri dapat terjadi melalui percikan saat bersin atau batuk antar manusia. Oleh karena itu penggunaan masker dan physical distancing telah beroperasi pada lingkungan perusahaan yang mewajibkan karyawannya menggunakan masker sebelum masuk ke kantor.

Untuk mencegah persebaran COVID-19 yang tidak terkendali ini, maka dibuatlah penelitian sistem deteksi masker dengan metode haar cascade pada era new normal COVID-19. Sistem deteksi masker ini menggunakan tools pycharm community edition 2020 dan python 3.8 module docs 8 . Sistem ini menggunakan beberapa library dengan meng-upgrade pip seperti scipy, pillow, matplotlib dan opencv contrib python.

Metode yang digunakan pada penelitian ini adalah haar cascade dimana algoritma ini merupakan salah satu model machine learning yang kerap kali digunakan sebagai pondasi aplikasi object detection (terutama face recognition) dalam sebuah gambar maupun video. Metode ini sering digunakan untuk mengenali area mana saja terdapat wajah manusia (face recognition) pada sebuah gambar menggunakan OpenCV [6]. Data yang digunakan pada penelitian ini adalah data dari orang yang menggunakan masker dan tidak menggunakan masker. Objek yang menggunakan dataset melalui proses training kemudian dideteksi oleh haar cascade apakah orang tersebut menggunakan masker atau tidak. Jika salah satu karyawan ada yang tidak menggunakan masker pada saat di dalam kantor maka alarm akan berbunyi.

\section{METODOLOGI}

Tahapan awal yang dilakukan pada penelitian sistem deteksi masker dengan metode haar cascade pada era new normal COVID-19 ini adalah melakukan studi literatur. Studi literatur dilakukan untuk menganalisa dan mencari sistem yang tepat untuk di aplikasikan, dan dapat memenuhi tujuan penelitian juga menyelesaikan permasalahan yang ada.

Tahapan selanjutnya adalah melakukan perancangan sistem. Pada tahapan ini dilakukan perancangan sistem deteksi masker dengan metode haar cascade pada era new normal COVID-19. Algoritma Haar menggunakan metode statistical dalam melakukan pendeteksian wajah. Metode ini menggunakan sample haarlike fetures [7]. Haarlike fetures digunakan dalam mendeteksi objek pada sebuah citra digital. Awalnya pengolahan gambar hanya dengan melihat nilai dari nilai RGB dari setiap pixel, namun metode ini ternyata tidaklah efektif. Viola dan Jones kemudian mengembangkannya sehingga terbentuk Haar-Like feature. Haar-Like feature memproses gambar dalam kotak-kotak, dimana dalam satu kotak terdapat beberapa pixel, per kotak itu pun kemudian diproses dan didapatkan perbedaan nilai yang menandakan daerah gelap dan terang. Nilai-nilai inilah yang nantinya dijadikan dasar image processing. Proses alur deteksi wajah dengan Haar cascade ditunjukkan pada gambar 1 [8].

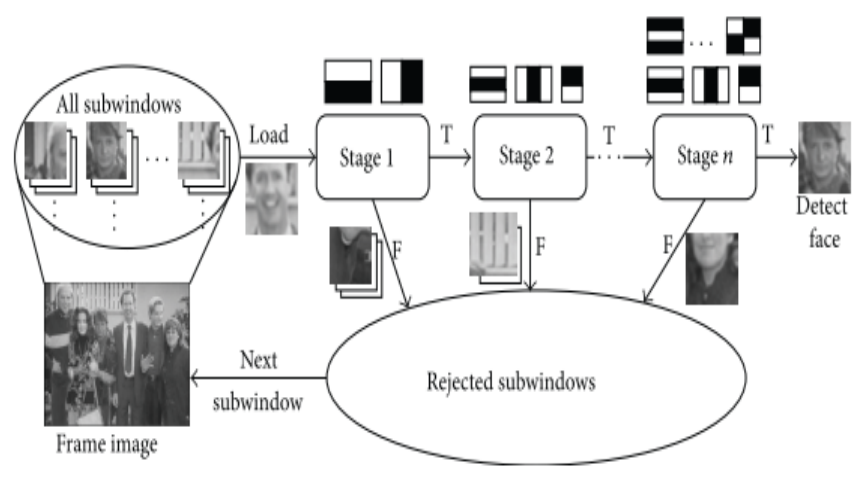

Gambar 1. Alur deteksi wajah dengan Haar cascade

Sistem ini menggunakan dataset yang datanya di tranning ke dalam tools pycharm community edition 2020 dan python 3.8 module docs 8. Pycharm adalah Integrated Development Environment (IDE) yang berfokus pada pengembangan project dengan Bahasa pemograman python. Pycharm di kembangkan oleh jetBrains, Pycharm merupakan IDE cross-platfrom yang artinya dapat dijalankan pada berbagai sistem informasi seperti Windows, Linux, dan Mac [9]. Terdapat beberapa library yang digunakan dengan mengupgrade pip seperti scipy, pillow, matplotlib dan opencv contrib python. Python dapat digunakan untuk berbagai keperluan pengembangan perangkat lunak dan dapat berjalan di berbagai macam sistem operasi karena sifatnya yang multiplatform. Pada kebanyakan sistem operasi linux, bahasa pemrograman ini menjadi standarisasi untuk disertakan dalam paket distribusinya. Seperti halnya bahasa pemrograman dinamis, python seringkali digunakan sebagai bahasa skrip [10]. Metode haar cascade digunakan untuk mendeteksi orang dan maskernya sehingga menghasilkan 2 kondisi bermasker atau tidak bermasker. Jika kondisi tidak bermasker maka alarm akan berbunyi hingga orang tersebut memakai masker. Tombol ESC digunakan untuk keluar dari aplikasi. Diagram proses dari rancangan sistem ini ditunjukkan pada gambar 2 .

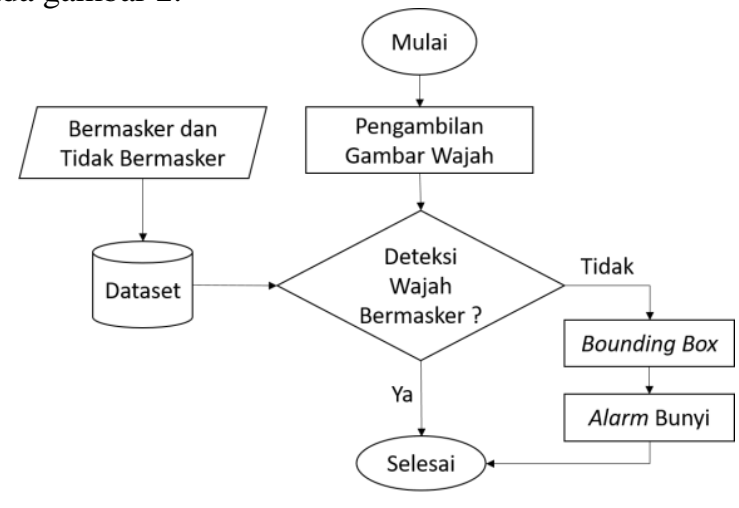

Gambar 2. Diagram proses 
Gambar 2 menunjukkan diagram proses dari sistem deteksi masker. Langkah awal yang dilakukan adalah pengambilan gambar wajah menggunakan kamera. Selanjutnya sistem akan mendeteksi apakah wajah menggunakan masker atau tidak menggunakan masker. Sistem akan mendeteksi wajah yang tidak menggunakan masker berdasarkan dataset wajah yang sudah dibuat sebelumnya. Dataset berisi data training wajah orang yang menggunakan masker dan tidak menggunakan masker.

Ketika wajah yang tertangkap kamera adalah wajah yang menggunakan masker, maka proses akan dihentikan. Sebaliknya, jika wajah yang tertangkap kamera adalah wajah yang tidak menggunakan masker, maka gambar wajah akan ditandai dengan bounding box. Alarm akan berbunyi jika ada wajah yang dikenali tidak menggunakan masker.

\section{HASIL DAN PEMBAHASAN}

Dalam penelitian sistem deteksi masker dengan metode haar cascade pada era new normal COVID-19 ini menggunakan sekelompok data yang kemudian dibagi menjadi 2 variabel, yaitu gambar orang pakai masker dan gambar orang yang tidak pakai masker. Kumpulan dataset tersebut ditunjukkan pada Gambar 3.

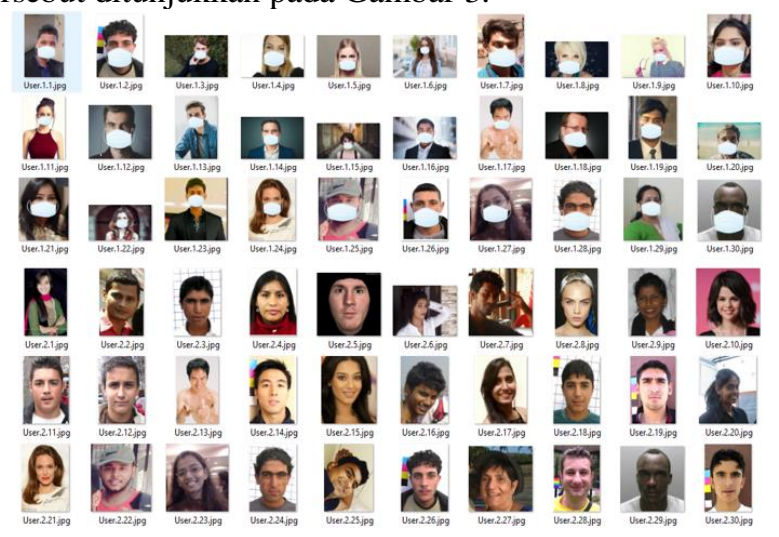

Gambar 3. Kumpulan dataset

Pada penelitian ini identifikasi dilakukan dengan source code cascadeclasifier yang berfungsi untuk klasifikasi pengenalan wajah dengan menggunakan masker serta wajah tanpa menggunakan masker. Pada souce code path $=$ 'dataset' proses ini dilakukan pembacaan gambar yang di peroleh pada proses training untuk pengenalan sehingga gambar yang dimasukkan dari kamera dicocokkan dengan gambar yang terdapat pada dataset dengan algoritma haarcascade

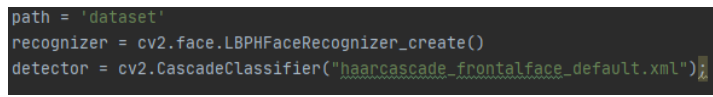

Gambar 4. Path database gambar

Pengujian deteksi dilakukan menggunakan metode haar cascade yang telah melakukan training wajah dengan mengambil wajah orang melalui kamera laptop seperti ditunjukkan pada gambar 5. Kemudian dengan menampilkan wajah tanpa menggunakan masker dan juga menggunakan masker pada kamera. Dari hasil pengujian terlihat bahwa sistem berjalan dengan baik dengan menampilkan pesan "Tanpa Masker" ketika tidak menggunakan masker, dan "Dengan Masker" ketika menggunakan masker. Hasil pengujian ditunjukkan pada Gambar 6.

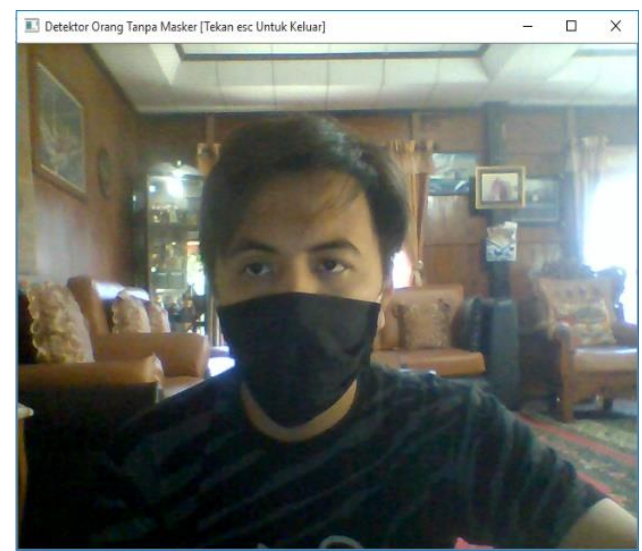

Gambar 5. Objek deteksi menggunakan masker

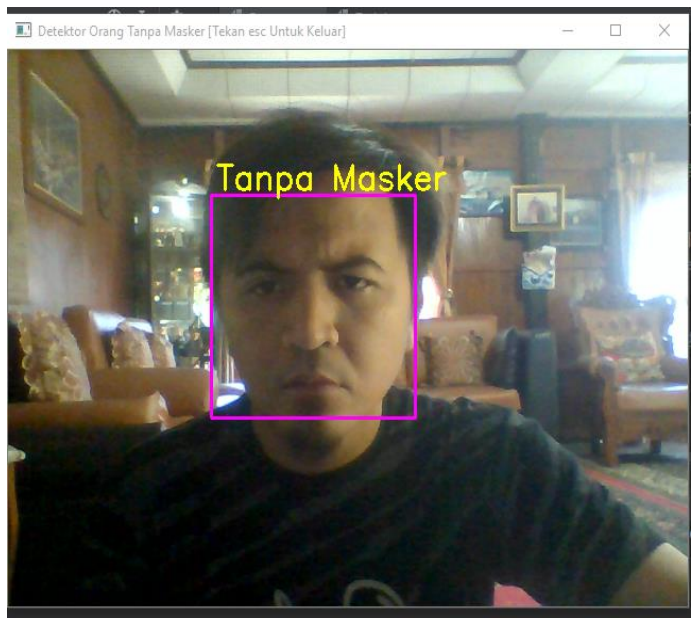

Gambar 6. Objek deteksi tidak menggunakan masker

Pengujian deteksi masker selanjutnya dilakukan dengan menampilkan 2 orang sebagai objek deteksi. Hasil pengujian menunjukkan bahwa sistem berjalan dengan baik dengan menampilkan pesan "Tanpa Masker" ketika ada salah satu orang yang tidak menggunakan masker, dan "Dengan Masker" ketika kedua orang tersebut menggunakan masker. Hasil pengujian ditunjukkan pada Gambar 7 dan Gambar 8. 


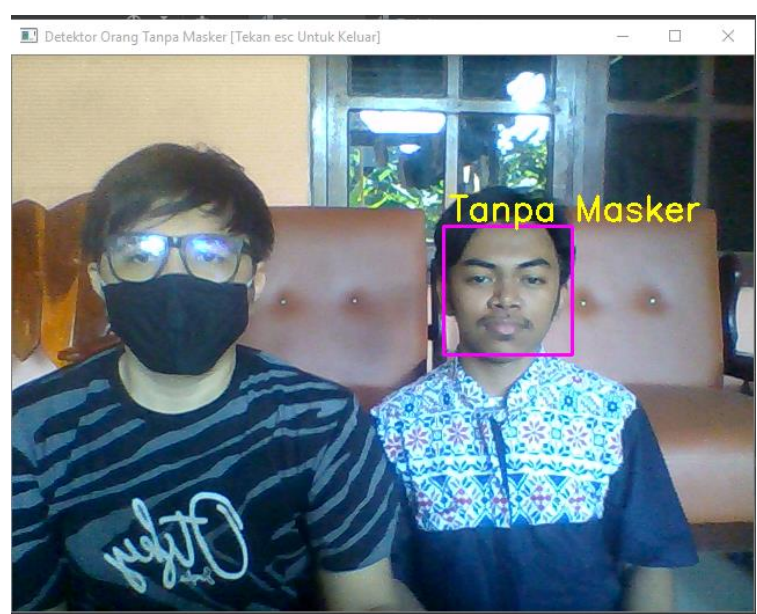

Gambar 7. Pengujian untuk 2 objek yang berbeda

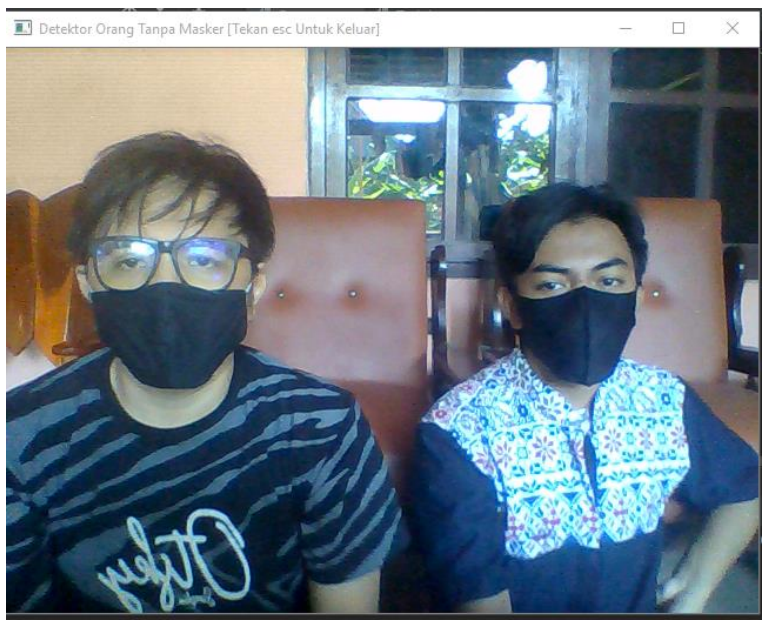

Gambar 8. Pengujian untuk 2 objek yang sama

Pengujian alarm pada saat orang tanpa masker dapat dilihat melalui source code pada gambar 9 sirine.wav. Pada source code winsound.playsound berfungsi untuk memainkan suara dengan format .wav di windows. Sehingga alarm akan berbunyi pada saat mendeteksi orang tanpa masker.

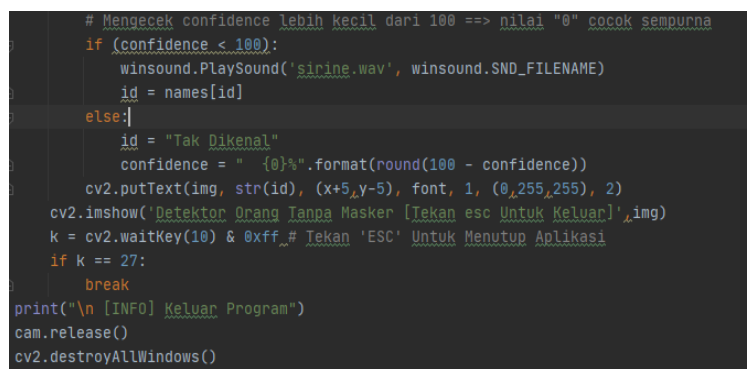

Gambar 9. Source code alarm

\section{KESIMPULAN}

Sistem deteksi masker dengan metode haar cascade pada era new normal COVID-19 dapat berjalan dengan baik, mampu mendeteksi masker yang digunakan oleh manusia dan juga dapat membunyikan alarm jika ada manusia yang tidak menggunakan masker untuk memberitahukan kepada petugas keamanan. Kekurangan dari sistem ini adalah pengambilan datasetnya yang belum realtime. Agar masker wajah terdeteksi dengan baik dibutuhkan kondisi cahaya yang lebih baik, karena jika lokasi pemasangan dilakukan di lokasi yang tidak cukup cahaya, masker detektor tidak cukup baik untuk mendeteksinya. Untuk penelitian selanjutnya, Sistem deteksi masker dengan metode haar cascade pada era new normal COVID-19 pengambilan datasetnya harus realtime. Selain itu, perlu menambahkan detail informasi posisi manusia yang tidak menggunakan masker dan mendeteksi lebih detail informasi data diri manusia yang tidak menggunakan masker.

\section{DAFTAR PUSTAKA}

[1] A. Gorbalenya et al., "Severe acute respiratory syndrome-related coronavirus: The species and its viruses - a statement of the Coronavirus Study Group,” Nat. Microbiol., pp. 1-15, Feb. 2020.

[2] WHO, "WHO Coronavirus Disease (COVID-19) Dashboard | WHO Coronavirus Disease (COVID-19) Dashboard," Who, 2020. [Online]. Available: https://covid19.who.int/?gclid=Cj0KCQjwoPL2BRDxARIsAEM m9y_SgyY134pvGeOELLPw4QQZM9nnugUYKmGOCQgVCA 1tmYAEzcpp3IaAnKREALw_wcB. [Accessed: 25-Jun-2020].

[3] R. K. Sinuraya, D. P. Destiani, I. M. Puspitasari, and A. Diantini, "Pengukuran Tingkat Kepatuhan Pengobatan Pasien Hipertensi di Fasilitas Kesehatan Tingkat Pertama di Kota Bandung," Indones. J. Clin. Pharm., vol. 7, no. 2, pp. 124-133, 2018.

[4] A. S. Prihantana and S. S. Wahyuningsih, "Hubungan pengetahuan dengan tingkat kepatuhan pengobatan pada pasien tuberkulosis di RSUD Dr. Soehadi Prijonegoro Sragen," J. Farm. Sains dan Prakt., vol. 2, no. 1, pp. 46-52, 2016.

[5] D. H. Wulandari, "Analisis Faktor-Faktor yang Berhubungan dengan Kepatuhan Pasien Tuberkulosis Paru Tahap Lanjutan Untuk Minum Obat di RS Rumah Sehat Terpadu Tahun 2015," J. Adm. Rumah Sakit Indones., vol. 2, no. 1, pp. 17-28, 2018.

[6] L. Wisesa, "OpenCV Face Recognition Berbasis Algoritma Haar Cascade," Purwadhika Connect, 2019. [Online]. Available: https://medium.com/purwadhikaconnect/opencv-face-recognitionberbasis-algoritma-haar-cascade-1a5e23d9e8cb. [Accessed: 26Jun-2020].

[7] V. K. Gudipati, O. R. Barman, M. Gaffoor, and A. Abuzneid, "Efficient facial expression recognition using adaboost and haar cascade classifiers," in 2016 Annual Connecticut Conference on Industrial Electronics, Technology \& Automation (CT-IETA), 2016, pp. 1-4.

[8] M. Kim, D. Lee, and K.-Y. Kim, "System architecture for realtime face detection on analog video camera," Int. J. Distrib. Sens. Networks, vol. 11, no. 5, p. 251386, 2015.

[9] PyCharm, "PyCharm: the Python IDE for Professional Developers by JetBrains," Jetbrains.Com, 2020. [Online]. Available: https://www.jetbrains.com/pycharm/. [Accessed: 25Jun-2020].

[10] J. W. Shipman, "Tkinter 8.5 reference: a GUI for Python," in Computer, 2013, pp. 1-118. 